\title{
The Effects of Different Discourse Moves on Students' Oral Output
}

\section{James Bury}

Shumei University

\begin{abstract}
This article investigates the effect of 10 different discourse moves on students' oral output when used in English conversation classes in a Japanese university. The 10 moves consisted of four question types and six other moves. It was found that the type of move employed by the teacher influenced both the length and type of output that the students produced, with three distinct groups being identified. Consequently, it is suggested that teachers should utilize a range of discourse moves in order to encourage student output, and to increase awareness of the possible various moves that they might encounter in authentic interactions.
\end{abstract}

本論では、日本の大学における英会話の授業で、10の異なるディスコ 一スムーブ (discourse moves一話し手が会話の流れを生み出すために何 をどう述べるかを選択していく談話手法) がどのように学生の発話に影 響を与えるのかを調査した。10の談話手法は質問形式が4つ、それ以外が 6つであつた。教師が用いたそれぞれの談話手法は学生の発話の長さと型 の両方に影響を与え、また、3つの明確なグループに分類できることが分 かった。その結果、学生の発話を助長すると同時に、実際のやりとりの中 で彼らが遭遇するかもしれない様々な手法をより認識させるためにも、教 師は多様な談話手法を用いるべきであることが示唆された。

lassroom interactions in formal education contexts are predominantly shaped by questions (Bury, 2014). Typical question-and-answer discourse patterns, such as IRE (Initiate-Respond-Evaluate) (Lemke, 1990; Mehan, 1998) and IRF (Initiate-Respond-Feedback) (Sinclair, 1992) are valuable tools when directing learning in the classroom as they provide the opportunity to initiate interaction and are effective for managing classroom behavior. However, research has indicated that by using alternatives to questions in their discourse moves, defined by Springer and Dick (2006, p. 106) as "a deliberate action taken by a teacher to encourage, facilitate, participate in, or influence ... discourse," teachers could encourage students to produce more oral output (Dashwood, 2005). It has also been argued that students should be exposed to a variety of discourse move types in order to make classroom interactions more authentic (Bury, 2018). This is important as teachers need to encourage students to communicate successfully in order to prepare them for real-life communicative contexts, not just formulaic, test-like speech patterns.
This study builds on the work conducted by Bury $(2014,2018)$ by exploring the effect of using four types of questions, and six teacher discourse moves other than questions, in the evaluation/feedback stage of IRE and IRF structures. This is explored through the amount and type of oral output that students produced in English communication classes in a Japanese university. This article differs from previous studies by using the question categories outlined by Wajnryb (1992). The 10 discourse moves (see Table 1) have been adapted from a combination of those identified by Bury (2014), Dashwood (2005), and Wajnryb (1992).

Table 1. Types of Discourse Moves

\begin{tabular}{|c|c|c|}
\hline Type & Process & Example \\
\hline Yes/No & $\begin{array}{l}\text { Can only be answered } \\
\text { with Yes or No }\end{array}$ & $\begin{array}{l}\text { Do you like } \\
\text { Japanese food? }\end{array}$ \\
\hline Display & $\begin{array}{l}\text { Asks for information } \\
\text { already known to the } \\
\text { asker }\end{array}$ & $\begin{array}{l}\text { What colour is } \\
\text { rice? }\end{array}$ \\
\hline Referential & $\begin{array}{l}\text { Asks for information } \\
\text { not already known to } \\
\text { the asker }\end{array}$ & $\begin{array}{l}\text { What did you eat } \\
\text { for dinner last } \\
\text { night? }\end{array}$ \\
\hline $\begin{array}{l}\text { Non-retrieval/ } \\
\text { imaginative }\end{array}$ & $\begin{array}{l}\text { Asks for opinions or } \\
\text { other non-retrieval } \\
\text { responses }\end{array}$ & $\begin{array}{l}\text { What is the } \\
\text { best place to } \\
\text { eat seafood in } \\
\text { Japan? }\end{array}$ \\
\hline $\begin{array}{l}\text { Reflective } \\
\text { statement }\end{array}$ & $\begin{array}{l}\text { Restatement of the } \\
\text { student comment }\end{array}$ & $\begin{array}{l}\text { Ah, you think } \\
\text { Japanese food is } \\
\text { the best. }\end{array}$ \\
\hline $\begin{array}{l}\text { Statement of } \\
\text { mind }\end{array}$ & $\begin{array}{l}\text { Reflection of the } \\
\text { teacher's own views on } \\
\text { the topic }\end{array}$ & $\begin{array}{l}\text { I think English } \\
\text { food is the best. }\end{array}$ \\
\hline $\begin{array}{l}\text { Declarative } \\
\text { statement }\end{array}$ & $\begin{array}{l}\text { Thought that occurs to } \\
\text { the teacher as a result } \\
\text { of what the speaker } \\
\text { said }\end{array}$ & $\begin{array}{l}\text { Many people like } \\
\text { Japanese food. }\end{array}$ \\
\hline $\begin{array}{l}\text { Statement of } \\
\text { interest }\end{array}$ & $\begin{array}{l}\text { Expressing an interest } \\
\text { in a person's views }\end{array}$ & That's interesting. \\
\hline $\begin{array}{l}\text { Speaker } \\
\text { referral }\end{array}$ & $\begin{array}{l}\text { Referring to a previous } \\
\text { speaker's statement }\end{array}$ & $\begin{array}{l}\text { That's the same } \\
\text { as Yuki. }\end{array}$ \\
\hline $\begin{array}{l}\text { Back- } \\
\text { channeling }\end{array}$ & $\begin{array}{l}\text { Gestures, verbal } \\
\text { signals, and pauses }\end{array}$ & [Nodding] \\
\hline
\end{tabular}




\section{Literature Review}

Classroom discourse and the way that students interact with their teachers strongly impact language learning and development, shaping the ways in which learners respond to instruction and communicate (Mondada \& Pekarek Doehler, 2004). Students can become accustomed to certain patterns of discourse (Hall, 2010), especially structures like IRE and IRF (henceforth IRE/F) (Mehan, 1998; Waring, 2009) and consequently find deviating from them difficult.

Within IRE/F interactions teachers are responsible for guiding the discourse and evaluating students' responses, controlling the type of interaction, who participates, and for how long (Hall \& Walsh, 2002). Consequently, students have little freedom to communicate in authentic, meaningful ways, which limits their opportunities to extend and elaborate on their utterances (Thoms, 2012). As IRE/F sequences prevent students from managing turn-taking, developing their ideas, and directing the progression of interactions, they place teachers in the position of expert, consolidating the acceptance of the traditional, asymmetrical teacher-student discourse patterns in which teacher talk is maximized (van Lier, 1988). Such teacher-centered activities can reduce student engagement (Donato \& Brooks, 2004), and thus impact their overall learning experience.

Although using IRE/F discourse patterns is a comfortable and convenient way of engaging students in conversation, previous research has indicated that the type of discourse moves teachers employ in their classroom interactions affects how fully students develop responses and how naturally they communicate (Bury, 2014, 2018). Furthermore, changing the discourse moves that teachers make in classroom interactions can lead to students participating more in whole-class discussion (Nassaji \& Wells, 2000). Subsequently, what would appear to be appropriate pedagogical behaviour, such as asking further questions at every opportunity, might actually limit students' participation in classroom interactions, negatively affecting their language acquisition.

\section{Method}

Data for this study were collected by taking two 10-minute recordings of four different English conversation classes in two consecutive lessons (a total of eight samples) at a private Japanese university. The four classes had an average of 12 students $(N=47)$ with TOEIC scores ranging from 250 to 500 , and the lessons had a strong focus on oral communication. The recordings were analyzed quantitatively, by counting the length of utterances the students produced in response to the different discourse moves made by the teacher, and qualitatively, by noting the type of language the students produced. Transcriptions of representative excerpts of the recordings using the Jefferson system (Jefferson, 2004) (see Appendix) were made in order to illustrate the findings.

Referential or non-retrieval/imaginative questions were chosen to initiate interactions as it was thought that they would be more effective in stimulating student output than yes/no or display questions. Then, following a student response, the teacher attempted to use the 10 discourse moves equally in the third stage. Although it was necessary for the teacher to try and use the full range of discourse moves in their classroom interactions so that a fair and comparable analysis could be made, it was also important that the data were produced as naturally as possible.

\section{Results and Discussion}

The results (see Table 2) indicate that the type of discourse moves employed by the teacher influenced the length of the students' responses, with an overall difference of 9.3 words per move being demonstrated between the highest ranking move, reflective statement, and the lowest, back-channeling. Despite some variation in the ranking of the length of responses to the different discourse moves between the classes, three groups of moves can be identified based on the overall rankings of the four classes. Reflective statements and speaker referrals encouraged noticeably more output than the other moves; non-retrieval/imaginative questions, statements of interest, referential questions, and declarative statements encouraged above average responses within a range of 1.8 words of the overall average; and display questions, yes/no questions, statements of mind, and back-channeling encouraged less student output than the mean. In particular, it should be noted that in all four of the classes, students produced the least output following back-channeling.

The differences in the overall lengths of responses and the variations in the rankings of the discourse moves that can be noted between classes might be attributed to the levels of the groups. The classes were intact groups and the students had been streamlined based on TOEIC scores (students in Class A had the highest scores, and students in Class D had the lowest scores). Although TOEIC test scores might not necessarily have had a significant impact on the students' speaking ability and willingness to produce more oral output, the levelling of students might explain the differences between the classes and the indication that some discourse moves affected some groups more than others. 
One possible reason that using reflective statements encouraged the longest responses from students is that such statements show students that their comments are being listened to, and thus are valued by teachers. This increases the students' motivation, confidence, and willingness to speak more (Bury, 2018). In terms of the type of output that was produced following reflective statements, it was noticeable that the students gave a range of different types of comments that departed from typical, formulaic answers. In the example excerpt below, the use of a reflective statement engaged the student. It encouraged them to expand on their ideas and give further contextualization by restating the previous point using a different grammatical structure and adding two extra sentences:

T: Wha:t was your idea?

S: (3.7) I wanted watch a ( ) movie (3.1) film.

T: (1.8) So you wanted to watch a film.

S: (3.4) Yes, (1.6) I thought to watch a film would ( ) best. I love movies. I always want to ( ) watch movie.

The finding that students provided relatively long responses after their teacher's incorporation of speaker referrals also supports previous stud- ies (Bury, 2014; Dashwood, 2005). This type of move enabled students to link their ideas to their classmates', which enhanced the opportunities for collaborative communication and the shared co-construction of understanding. In the example excerpt below, the student (S1) restates her classmate's opinion and then confirms that their opinions match with a further sentence before adding another supporting sentence. This allows S2 the opportunity to re-enter the interaction. This is an important finding as students can often feel that their classroom interactions are isolated and that there is a lack of cohesion among classmates. This can cause them to become less engaged and to "switch off" once their turn has passed:

T: What do you: think about horror films [S1]?

S1: (3.2) Horror (2.1) I don't like them.

T: (1.8) Ah, that's the sa:me as [S2].

S1: (1.6) Yes. (2.7) She doesn't like either. (2.0) We are the same. They are (1.6) (Japanese) (2.9) grotesque.

S2:Yes!

The use of non-retrieval/imaginative questions generally prompted long answers and the students produced more output than was minimally required.

Table 2. Average Length of Student Responses to the 10 Discourse Moves

\begin{tabular}{|c|c|c|c|c|c|c|c|c|c|c|}
\hline \multirow[t]{2}{*}{ Move Type } & \multicolumn{2}{|c|}{ Class A } & \multicolumn{2}{|c|}{ Class B } & \multicolumn{2}{|c|}{ Class C } & \multicolumn{2}{|c|}{ Class D } & \multicolumn{2}{|c|}{ All Classes } \\
\hline & Words & Rank & Words & Rank & Words & Rank & Words & Rank & Words & Rank \\
\hline Yes / No & 7.5 & 9 & 7.3 & 8 & 5.5 & 8 & 6.7 & 8 & 6.8 & 8 \\
\hline Display & 8.5 & 8 & 7.4 & 7 & 6.1 & 7 & 9.1 & 6 & 7.8 & 7 \\
\hline Referential & 11.4 & 4 & 9.8 & 6 & 10.7 & 4 & 9.0 & 7 & 10.2 & 5 \\
\hline $\begin{array}{l}\text { Non-retrieval/ } \\
\text { imaginative }\end{array}$ & 12.3 & 3 & 11.7 & 4 & 9.3 & 5 & 10.7 & 2 & 11.0 & 3 \\
\hline $\begin{array}{l}\text { Reflective state- } \\
\text { ment }\end{array}$ & 14.7 & 1 & 12.7 & 2 & 11.9 & 2 & 12.3 & 1 & 12.9 & 1 \\
\hline $\begin{array}{l}\text { Statement of } \\
\text { mind }\end{array}$ & 8.7 & 7 & 5.0 & 9 & 5.3 & 9 & 4.3 & 9 & 5.8 & 9 \\
\hline $\begin{array}{l}\text { Declarative } \\
\text { statement }\end{array}$ & 10.1 & 6 & 11.4 & 5 & 8.5 & 6 & 9.7 & 4 & 9.9 & 6 \\
\hline $\begin{array}{l}\text { Statement of } \\
\text { interest }\end{array}$ & 10.3 & 5 & 12.7 & 2 & 11.1 & 3 & 9.4 & 5 & 10.9 & 4 \\
\hline Speaker referral & 14.5 & 2 & 13.3 & 1 & 12.7 & 1 & 10.3 & 3 & 12.7 & 2 \\
\hline $\begin{array}{l}\text { Back- } \\
\text { channeling }\end{array}$ & 4.7 & 10 & 3.1 & 10 & 4.3 & 10 & 2.3 & 10 & 3.6 & 10 \\
\hline $\begin{array}{l}\text { Total average } \\
\text { words }\end{array}$ & 10.3 & & 9.4 & & 8.5 & & 8.4 & & 9.2 & \\
\hline
\end{tabular}


However, the output tended to be more "test-like," with students producing short sentences that did not link to other previous interactions. The sample below demonstrates this with three reasons given in response to the teachers' question. This was also often the case following referential questions:

T: What did you watch last night?

S: (1.6) Variety show.

T: (.) Why do think (.) why are variety shows so popular in Japan?

S: (1.8) Why? (2.7) They like the comedy. (2.1) It is fun (Japanese) (1.7) Yes (.) fun. Watching variety is (2.6) relax.

Following statements of interest, the students often expanded on utterances made in their previous moves, producing more output than would be minimally required to fulfil their role in the interactions. This was also evident in the responses to declarative statements. In the example excerpt below, two extra sentences are produced:

T: Do you: prefer watching TV alone (.) or with friends?

S: (1.8) I (.) like alone.

T: (1.3) That's interesting.

S: (1.9) To watch with (.) other people is noisy. (2.2) I like to concentrating (.) so alone is good.

In response to Yes/No questions, the students were generally able to reply and answer, but there was little elaboration. In the majority of cases only a single reason or extra sentence was produced, as in the example excerpt below. This was also apparent in the students' responses to display questions:

T: What's your favourite film?

S: (2.7) I don't know. (Japanese) (.) I watch TV.

$\mathrm{T}$ : (2.2) Japanese TV?

S: (1.4) Yes. It's better for me.

In response to the teacher's use of a statement of mind, students commonly produced short utterances. This could be attributed to students possibly interpreting the move as an evaluation, which might have created a sense of finality, thus discouraging further language production. This is well illustrated in the excerpt below:

T: Do you like (.) action or romance more?

S: (2.7) Action (.) They are exciting.

$\mathrm{T}$ : Yeah (.) Action is better.

S: (2.2) Yes.
Students produced by far their shortest utterances in response to back-channelling. Analysis of the recordings indicated that students often misunderstood the teacher's intentions, leading to relatively long pauses in the classroom discourse.

\section{Limitations}

Although this study produced some interesting findings that support previous studies, there are a number of limitations that must be acknowledged. Due to the relatively low number of participants $(N=47)$, no statistical analysis was conducted, thus any noted differences in student responses to the discourse moves might not be statistically significant. Also, unlike a study conducted by Consolo (2000), this research did not investigate any possible variations in the use of different moves by native speaker teachers and non-native speaker teachers. Furthermore, it was outside the scope of this paper to examine student-student interactions following the introduction of different moves. In addition, studies by Hellermann $(2003,2005)$ indicated that the timing of the teacher's move can affect student output, but this was not considered during this study. Finally, the number of times the discourse moves were used by the teacher was not recorded and this might have affected how comfortable students were when attempting to respond to certain moves. In future research on this topic, these variables should be taken into account. Furthermore, the most effective ways to introduce and practice the different moves, and any differences in results at different stages throughout the course as students become more comfortable responding to the greater range of utterances, would be interesting and useful additions.

\section{Conclusion}

This research has indicated that the use of different teacher discourse moves can affect the amount of oral output and also the type of output that students produce. In other words, the discourse moves employed by teachers can either aid or hinder the length and quality of interaction. The pedagogical implication of this is that teachers should try to regularly expose students to the various different moves that they might encounter in authentic, everyday interactions. Doing this would provide students with the opportunity to improve their communicative competence and increase their confidence when responding to different discourse moves.

As some of the discourse moves employed in this research were regularly misinterpreted or misunderstood by the students, it might be beneficial for teachers to get further training in how to effectively 
incorporate different moves into their classroom discourse or practise using them more often with their students. This could help improve the fluidity and authenticity of their interactions and enable students to better recognize the intention of the moves and respond to them appropriately.

\section{References}

Bury, J. (2014). Encouraging more student output: Alternatives to questions. Journal of Second Language Teaching and Research, 3(1), 95-106. Retrieved from http://pops.uclan.ac.uk/index.php/jsltr/article/ viewFile/246/105

Bury, J. (2018). Using different moves in classroom interactions, JALT PanSIG Conference 2018, Tokyo: Toyo Gakuen University. https://www.academia.edu/36676428/ Using_Different_Moves_in_Classroom_Interactions_ JALT_PanSIG_Conference_Toyo_Gakuen_University_ May_19-20_2018

Consolo, D. A. (2000). Teachers' action and student oral participation in classroom interaction. In J. K. Hall \& L. S. Verplaetse (Eds.), Second and foreign language learning through classroom interaction (pp. 91-107). Mahwah, NJ: Lawrence Erlbaum Associates.

Dashwood, A. (2005). Alternatives to questioning: Teacher role in classroom discussion. Asian EFL Journal, 7(4), 144-165. Retrieved from https://www.asian-efljournal.com/1338/quarterly-journal/alternatives-toquestioning-teacher-role-in-classroom-discussion/

Donato, R., \& Brooks, F. B. (2004). Literary discussions and advanced speaking functions: Researching the (dis) connection. Foreign Language Annals, 37(2), 183-199. https://doi.org/10.1111/j.1944-9720.2004.tb02192.x

Hall, J. K. (2010). Interaction as method and result of language learning. Language Teaching, 43(2), 202-215. https://doi.org/10.1017/S0261444809005722

Hall, J. K., \& Walsh, M. (2002). Teacher-student interaction and language learning. Annual Review of Applied Linguistics, 22, 186-203. https://doi.org/10.1017/ S0267190502000107

Hellermann, J. (2003). The interactive work of prosody in the IRF exchange: Teacher repetition in feedback moves. Language in Society, 32, 79-104. https://doi. org/10.1017/S0047404503321049

Hellermann, J. (2005). Syntactic and prosodic practices for cohesion in series of three-part sequences in classroom talk. Research on Language and Social Interaction, 38, 105-130. https://doi.org/10.1207/s15327973rlsi3801_4

Jefferson, G. (2004). Glossary of transcript symbols with an introduction. In G. H. Lerner (Ed.), Conversation analysis: Studies from the first generation (pp. 13-32). Philadelphia, PA: John Benjamins.

Lemke, J. L. (1990). Talking science: Language, learning, and values. Norwood, NJ: Ablex.

Mehan, H. (1998). The study of social interaction in educational settings: Accomplishments and unresolved issues. Human Development, 41, 245-269. https://doi. org/10.1159/000022586
Mondada, L., \& Pekarek Doehler, S. (2004). Second language acquisition as situated practice: Task accomplishment in the French second language classroom. Modern Language Journal, 88, 501-518. https://doi. org/10.1111/j.0026-7902.2004.t01-15-.x

Nassaji, H., \& Wells, G. (2000). What's the use of "triadic dialogue"? An investigation of teacher-student interaction. Applied Linguistics, 21(3), 376-406. https://doi. org/10.1093/applin/21.3.376

Sinclair, J. (1992). Priorities in discourse analysis. In M. Coulthard (Ed.), Advances in spoken discourse analysis (pp. 79-88). London: Routledge.

Springer, G. T., \& Dick, T. (2006). Making the right (discourse) moves: Facilitating discussion in the mathematics classroom. Mathematics Teacher, 100(2), 105-109. Retrieved from https://pll.asu.edu/p/system/files/lrm/ attachments/MT\%20discourse\%202006.pdf

Thoms, J. J. (2012). Classroom discourse in foreign language classrooms: A review of the literature. Foreign Language Annals, 45, S8-S27. https://doi.org/10.1111/ j.1944-9720.2012.01177.x

van Lier, L. (1988). The classroom and the language learner. London: Longman.

Wajnryb, R. (1992). Classroom observation tasks: A resource book for language teachers and trainers. Cambridge, England: Cambridge University Press.

Waring, H. Z. (2009). Moving out of IRF (initiation-response-feedback): A single case analysis. Language Learning, 59(4), 796-824. https://doi.org/10.1111/j.14679922.2009.00526.x

\section{Appendix}

\section{Summary of Transcription Notation}

(.) Just noticeable pause

(.3) Examples of timed pause

wo:rd Colons show that the speaker has stretched the preceding sound

word Underlined sounds are louder

\section{James Bury is an associate} professor working in the Kanto region of Japan. He has taught in a range of universities, colleges, and schools in England, Thailand, Vietnam, and Japan. His research interests include classroom discourse, developing students' communicative confidence, and teaching English for

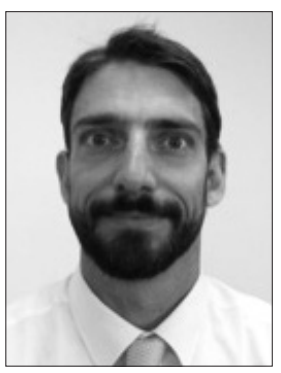
specific purposes. 